\title{
Rationalization of Rainfall Station In Ternate Island
}

\author{
Ega Widyawati ${ }^{1}$, Nani $\mathrm{Nagu}^{1 *}$, Muhammad Rizal $^{1}$, K.M. Zulkarnain ${ }^{1}$ and Oki Syafrel ${ }^{2}$ \\ ${ }^{1}$ Civil Department, Engineering Faculty, Khairun University, 97718, Ternate, Indonesia \\ ${ }^{2}$ North Moluccas River Basin Office, 97716 , Ternate, Indonesia
}

\begin{abstract}
Good rainfall data can be obtained from recordings that are maintained and monitored continuously. Thus, the more rain stations there are, the more detailed the rainfall data will be. The rain station network density is expressed as the area of the watershed represented by one rain station. Meanwhile, the pattern of distribution of rain stations states the location of the placement of rain stations in the watershed. Ternate Island with an area of $76 \mathrm{~km} 2$ and has stations located in Akehuda Village, Gamayou Village, Tabona Village, Sasa Village, Kastela Village, and Sulamadaha Village. This study aims to rationalize the density of rainfall stations in Ternate Island. Rationalization of rainfall stations using the Kagan-Rodda method. The results obtained for the rationalization of rainfall stations with a total of 5 rain gauge stations spread across the city of Ternate, which are located in the Tabam, Gamayou, Sasa, Dorpedu, and Togafo areas with a grading error of $19.27 \%$ with a network density of $4.17 \mathrm{Km}^{2} /$ station.
\end{abstract}

Keywords: Rationalization, Rain Station, Density

\section{Introduction}

Hydrological calculations require accurate, timely, and long-term rainfall data to assist the development, research, management, conservation, and control of the destructive power of water resources. Because it is used to create basic plans, its data should be appropriately recorded [1]. Hydrological station data are expected to be adequately produced using appropriate methods and competent human resource quality. Its accuracy dramatically depends on the station's capability to monitor the condition of the hydrological characteristics of a flow area accurately and correctly [2]. The necessity for better documenting and processing all aspects of precipitation to analyze and quantify the changing character of precipitation [3]. Agrobusinesses such as crop forecasting, water resource management, civil defense through drought or flood mitigation, and more benign economic returns through, for example, the removal of particulate pollution from the atmosphere, all benefit from the monitoring and measuring precipitation [4]. At a variety of scales and for a range of consumers, accurate precipitation measurement is required.

Precipitation measurements at local, fine scales with quick access to data (low latency) are necessary for flash flood research, but longer-term observations with less strict geographical, temporal, and latency criteria will suffice for drought studies [5],[6]. There are two problems that had to consider for determining area rainfall, such as the number and distribution pattern of rainfall stations[5],[7]. The inadequate rain stations and uneven distribution patterns will cause errors in monitoring primary hydrological data in a watershed. The resulting data is incorrect, and the results of planning, research, and management of water resources are inefficient and ineffective [[7]. To anticipate these errors, WMO recommends a minimum density of rain station networks in several areas, and a watershed should have rainfall stations that represent the density of the minimum rainfall station network that covers 100 $250 \mathrm{~km} 2 /$ station [7],[8]. Therefore, it is necessary to install rain stations that are evenly distributed and represent rainfall events in various topographical forms. Good rainfall data can be obtained from recordings that are maintained and continuously monitored [1], [9]. The more rain stations there are, the more detailed the recorded rainfall data. The density of the rain station network is expressed as the area of the watershed represented by one rain station. In contrast, the pattern of distribution of rain stations states the location of the placement of rain stations in the watershed [1], [7], [10][11].

Ternate island has an area of $76 \mathrm{~km}^{2}$ and has a reasonably diverse topography with six rainfall stations. The rain post points are located in Akehuda Village, Gamayou Village, Tabona Village, Sasa Village, Kastela Village, and Sulamadaha Village. However, Given the importance of rainfall data information on irrigation infrastructure, the research aims to rationalize the density of rainfall stations in Ternate City.

The Kagan method is used to measure the density of the rain station network in the watershed. The Kagan method's density calculation begins by using the correlation coefficient between rain stations for monthly rainfall[1], [5], [7], [12], [13].

\section{Methods}

This study was carried out at Ternate City with number area of $76 \mathrm{~km}^{2}$ and had 6 rainfall stations. The location of rainfall station can be seen on the figure 1 . 
The characteristic of rainfall data required for the research was yearly rainfall (2014-2020) and maximum daily rainfall (2014-2020).

There were two essential components to consider when designing a rainfall station scheme.

The items in enquiry were the number and location of rainfall stations. The steps for designing a rainfall station scheme were as follows:[5],[7][11]. There are several ways to determine the rain station network. Still, the Kagan-Rodda method is relatively simple in its application regarding the required data and calculation steps. The advantage of this method is that the number of rain stations can be set to a certain level of accuracy, and this method also provides a clear pattern of placement and distribution of rain stations[2].Kagan (1972) conducted a study in tropical areas where the rainfall is local, and the distribution area is not comprehensive, the space for rain varies with a specific return period, although in reality, it shows a correlation at a particular stage.

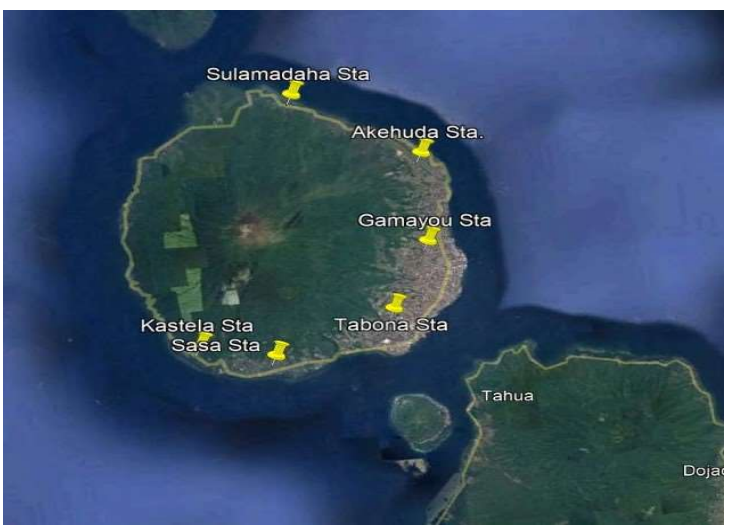

Fig 1. Location of the Rainfall Station

In general, the calculation steps carried out in planning the Kagan-Rodda network are as follows[5]: 1) Analyzing the hydrology to test the quality of the data; 2) Analyzing the regional average rainfall with Thiessen Polygons; 3) Analyzing the density of the rain station network based on the WMO standard; 4) Calculating the coefficient of variation from the calculation of the

Table 2. Maximum Monthly Rainfall Data

\begin{tabular}{|c|c|c|c|c|c|c|c|c|c|}
\hline \multirow{3}{*}{ No } & \multirow{3}{*}{ Rainfall Station } & \multicolumn{7}{|c|}{ Maximum Monthly Rainfall (mm) } & \multirow{3}{*}{$\begin{array}{l}\text { Monthly Rainfall } \\
\text { Maximum } \\
\text { Average }(\mathrm{mm})\end{array}$} \\
\hline & & 2014 & 2015 & 2016 & 2017 & 2018 & 2019 & 2020 & \\
\hline & & \multicolumn{7}{|c|}{ Maximum Monthly Rainfall } & \\
\hline \multirow{2}{*}{1} & \multirow{2}{*}{ Akehuda } & Jan & June & Desc & Jan & July & April & April & \multirow{2}{*}{336.62} \\
\hline & & 376.8 & 184.9 & 513.3 & 367.1 & 324.2 & 306.4 & 283.7 & \\
\hline \multirow{2}{*}{2} & \multirow{2}{*}{ Gamayou } & June & May & Dec & May & Nov & Apr & Aug & \multirow{2}{*}{392.35} \\
\hline & & 232.5 & 402 & 765 & 477 & 291 & 326 & 253 & \\
\hline \multirow{2}{*}{3} & \multirow{2}{*}{ Tabona } & Jan & May & Dec & June & July & April & Aug & \multirow{2}{*}{343.05} \\
\hline & & 177 & 223.3 & 408.4 & 497.8 & 428.7 & 377.7 & 288.5 & \\
\hline \multirow{2}{*}{4} & \multirow{2}{*}{ Sasa } & Jan & June & Dec & July & July & Apr & Aug & \multirow{2}{*}{458.1} \\
\hline & & 359.10 & 181.99 & 592.5 & 614 & 347.5 & 370.5 & 366 & \\
\hline \multirow{2}{*}{5} & \multirow{2}{*}{ Katela } & Feb & May & Dec & June & Aug & Apr & July & \multirow{2}{*}{222.43} \\
\hline & & 369 & 74.81 & 174.20 & 152 & 108.04 & 106.91 & 572.5 & \\
\hline \multirow{2}{*}{6} & \multirow{2}{*}{ Sulamadaha } & Jan & May & Dec & June & July & April & Aug & \multirow{2}{*}{343.06} \\
\hline & & 177 & 223.3 & 408.4 & 497.8 & 428.7 & 377.7 & 288.5 & \\
\hline
\end{tabular}

regional average rainfall; 5) Calculating the correlation coefficient value between rain posts; 6) Find the distance between rain posts; 7) Connect the correlation coefficient and the distance between rain posts on an exponential graph; 8) Get the values of $r(0)$ and $d(0)$ from an exponential graph; 9) Analysis of the density of the rain post network the Kagan-Rodda method, by calculating the value of the alignment error (Z1) and the interpolation error $(Z 3)$;10) Determining the maximum value of the smoothing error for $5 \%$, the value of $n$ is obtained as the number of rainfall stations; 11) Rationalization of the distribution of rain stations by depicting the Kagan-Rodda triangle.

\section{Result and Discussion}

\subsection{Location of Rainfall Observation Station}

For the location of rainfall measurement stations in Ternate, there are six stations which can be seen in table 1.

Table 1. Location of the rain gauge

\begin{tabular}{llrc}
\hline \multirow{2}{*}{ No } & \multirow{2}{*}{ Station } & \multicolumn{2}{c}{ Position } \\
& & Longitude & Latitude \\
\hline 1 & Akehuda & $127^{\circ} 22^{\prime} 53.6^{\prime \prime} \mathrm{E}$ & $0^{\circ} 49^{\prime} 45.0^{\prime \prime} \mathrm{N}$ \\
2 & Gamayou & $127^{\circ} 22^{\prime} 45.0^{\prime \prime} \mathrm{E}$ & $0^{\circ} 47^{\prime} 45.0^{\prime \prime} \mathrm{N}$ \\
3 & Tabona & $127^{\circ} 21^{\prime} 59.9^{\prime \prime} \mathrm{E}$ & $0^{\circ} 46^{\prime} 18.3^{\prime \prime} \mathrm{N}$ \\
4 & Sasa & $127^{\circ} 19^{\prime} 50.8^{\prime \prime} \mathrm{E}$ & $0^{\circ} 45^{\prime} 29.2^{\prime \prime} \mathrm{N}$ \\
5 & Kastela & $127^{\circ} 18^{\prime} 32.9^{\prime \prime} \mathrm{E}$ & $0^{\circ} 45^{\prime} 51.5^{\prime \prime} \mathrm{N}$ \\
6 & Sulamadaha & $127^{\circ} 20^{\prime} 13.7^{\prime \prime} \mathrm{E}$ & $0^{\circ} 51^{\prime} 24.0^{\prime \prime} \mathrm{N}$ \\
\hline
\end{tabular}

\subsection{Rainfall Data}

Rainfall data was used for seven years from 2014 2020, taken from six rain gauge points using the observatory ombrometer rain gauge, with 24-hour recording. 


\subsection{Distance Between Rainfall Stations}

The distance between rain gauge stations is determined by measuring the position map of the bulk measuring station from one station to another. From the measurement results obtained the distance between stations is as follows:

Tabel 3. Distance Between Rainfall Stations

\begin{tabular}{llllllll}
\hline \multirow{2}{*}{ No } & \multirow{2}{*}{ Station } & \multicolumn{6}{c}{ Distance Between Rainfall Stations $(\mathbf{K m})$} \\
\cline { 3 - 7 } & & Akehuda & Gamayou & Tabona & Sasa & Kastela & Sulamadaha \\
\hline 1 & Akehuda & 0 & 3.67 & 6.69 & 10.97 & 13.48 & 5.79 \\
2 & Gamayou & 3.67 & 0 & 3.2 & 7.46 & 8.55 & 8.19 \\
3 & Tabona & 6.69 & 3.2 & 0 & 4.27 & 6.46 & 9.95 \\
4 & Sasa & 10.97 & 7.46 & 4.27 & 0 & 2.5 & 10.93 \\
5 & Kastela & 13.48 & 8.55 & 6.46 & 2.5 & 0 & 10.68 \\
6 & Sulamadaha & 5.79 & 8.19 & 9.95 & 10.93 & 10.68 & 0 \\
Average & 6.767 & 5.178 & 5.095 & 6.022 & 6.945 & 7.590 \\
\hline
\end{tabular}

\subsection{Rainfall Station Distance and Correlation}

To determine the amount of the correlation between rain stations and to estimate the magnitude of the mistake that occurs, correlation analysis between rain stations is required. It is not required to consider the direction of the direction for both daily and monthly rainfall when evaluating the link between the distance between stations and the correlation coefficient since it has no impact on the size of the correlation. Then calculate the average distance between the reviewed stations and the rest of the stations. Recapitulation. The following table shows the average distance from all stations to the stations under consideration, as well as the correlation coefficient by each station:

Tabel 4. Relationship between station distance and correlation coefficient (r)

\begin{tabular}{llcc}
\hline No & Station & $\begin{array}{c}\text { Average } \\
\text { Distance of } \\
\text { Other Station } \\
\text { to Posts (Km) }\end{array}$ & r monthly \\
\hline 1 & Akehuda & 6.767 & 0.667 \\
2 & Gamayou & 5.178 & 0.597 \\
3 & Tabona & 5.095 & 0.493 \\
4 & Sasa & 6.022 & 0.918 \\
5 & Kastela & 6.945 & 0.943 \\
6 & Sulamadaha & 7.590 & 0.513 \\
\hline
\end{tabular}

From the results of the correlation coefficient and the distance between rain stations, the exponential graph is described as follows:

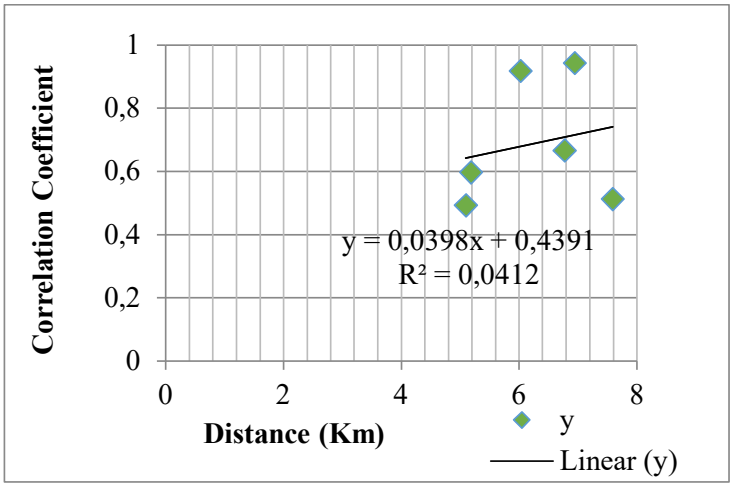

Fig.1. Exponential Graph

Based on the graph, $\mathrm{r}(\mathrm{o})=0.039$ and $\mathrm{d}(\mathrm{o})=1 / 0.439=$ $2.28 \mathrm{~km}$ were estimated.

\subsection{Alignment Error, Interpolation Error}

Based on equation (2.6), (2.7) it can be calculated respectively the smoothing error (Z1) and interpolation error (Z3) for monthly rainfall in Ternate Island as follows:

An example of calculating the smoothing error $(Z 1)$ and interpolation error (Z3) for monthly rainfall and the length of the side of the Kagan Rodda network.

Monthly $\mathrm{CV}=0.805$

$\mathrm{r}(0)=0.039$

$\mathrm{d}(0)=2.28$

$\mathrm{A}=76 \mathrm{Km} 2$

$\mathrm{N}=6$ stations

- Alignment error (Z1)

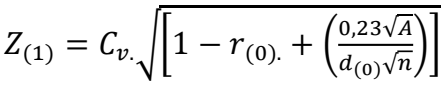

$$
\begin{aligned}
& \mathrm{Z} 1=0.20 \\
& Z 1=19.72 \%
\end{aligned}
$$


- Interpolation error (Z3)

$$
\begin{aligned}
& Z_{(3)}=C_{v} \sqrt{\left[\frac{1}{3}\left(1-r_{(0)}\right)+\frac{0,52 \cdot r_{(0) \cdot} \cdot \sqrt{\frac{A}{n}}}{d_{(0)}}\right]} \\
& Z 3=0,49 \\
& Z 3=48.54 \%
\end{aligned}
$$

\subsection{Rain Station Network Density Evaluation}

The data that has been calculated and analyzed by the Kagan-Rodda method has shown that the number of existing stations is sufficient for rainfall. The number of stations planned for Kagan-Rodda is 5 new rain stations with a smoothing error of $19.27 \%$ and an interpolation error of $48.54 \%$ which has a density of $4.17 \mathrm{Km} /$ station. The following is a picture of the placement of the old station in the city of Ternate before describing the Kagan Rodda nets.

With the lengths of the sides of the Kagan-Rodda triangle, which is then plotted on the map of Ternate City. The Kagan-Rodda triangular nets are shifted in such a way by shifting the vertices according to the number of stations obtained. The following are the nets of the equilateral triangle of the Kagan-Rodda Method in the Ternate City Area.

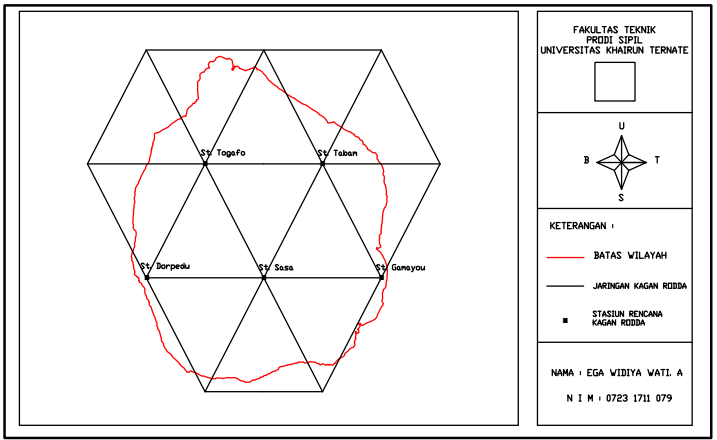

Fig 2 The net of the equilateral triangle Kagan-Rodda method.

The picture above shows the planned Kagan-Rodda station as many as 5 stations. Spread over the Tabam, Gamayou, Sasa, Dorpedu and Togafo areas. With an alignment error of $19.27 \%$ which has a density of 4.17 $\mathrm{Km} /$ station.

\section{Conclusion}

Based on the results of the analysis and discussion conducted on the rationalization of rainfall stations in Ternate island then the following conclusions can be drawn that the results of the analysis of the need for rainfall stations in Ternate City using the Kagan-Rodda method found a total of 5 rain gauge stations spread across Ternate island, which are located in the Tabam, Gamayou, Sasa, Dorpedu, and Togafo areas with a grading error of $19.27 \%$ and the density results obtained are $4.17 \mathrm{Km}^{2} /$ station.

\section{References}

[1] F. Pramono, S. Suripin, and W. Sulistya, "Rationalization of Rain Stations in the Ciliwung Cisadane River Basin," ripublication.com, vol. 12, pp. 2957-2963, (2019), Accessed: Sep. 10,( 2021). [Online]. Available:

https://www.ripublication.com/irph/ijert19/ijert v12n12_120.pdf.

[2] F. Yudha Pramono and W. Sulistya, "Rationalization of Rain Stations in the Ciliwung Cisadane River Basin," Int. J. Eng. Res. Technol., vol. 12, pp. 2957-2963, (2019), Accessed: Aug. 14, 2021. [Online]. Available: http://www.irphouse.com.

[3] K. E. Trenberth, A. Dai, R. M. Rasmussen, and D. B. Parsons, "The Changing Character of Precipitation," Bull. Am. Meteorol. Soc., vol. 84, no. 9, pp. 1205-1218, Sep. (2003), doi: 10.1175/BAMS-84-9-1205.

[4] C. Kidd et al., "So, how much of the Earth's surface is covered by rain gauges?," Bull. Am. Meteorol. Soc., vol. 98, no. 1, pp. 69-78, (2017), doi: 10.1175/BAMS-D-14-00283.1.

[5] H. Prasetijo, L. Montarcih, and L. Prasetyorini, "ORIGINAL ARTICLES Analysis of Average Rainfall Using Kagan-Rodda," J. Appl. Sci. Res., vol. 7, no. 3, pp. 309-313, (2011).

[6] UNESCO and INBO, The handbook on water information systems: administration, processing and exploitation of water-related data, no. March. (2018).

[7] E. Suhartanto and L. M. Limantara, "Density of Rainfall Stations in Kahayan Watershed Centre Kalimantan Province of Indonesia," J. Basic Appl. Sci. Res., vol. 2, no. 12, pp. 12952-12960, (2012).

[8] B. Wicaksono and E. Suhartanto, "Evaluasi Dan Perencanaan Kerapatan Jaringan Pos Hujan Dengan Metode Kriging Menurut Rekomendasi WMO (World Meteorological Organization) Di Wilayah Sungai Rokan Provinsi Riau," J. Mhs. Jur. Tek. Pengair., vol. 2, no. 1, p. 22, (2018).

[9] M. P. Curtarelli, C. D. Rennó, and E. H. Alcântara, "Evaluation of the Tropical Rainfall Measuring Mission 3B43 product over an inland area in Brazil and the effects of satellite boost on rainfall estimates," J. Appl. Remote Sens., vol. 8, no. 1, p. 083589, (2014), doi: 10.1117/1.jrs.8.083589.

[10] F. Ayu, R. Shiami, and U. Lasminto, "Rationalization of Hydrology Station Network Using Rainfall Ground and Satellite Data," Int. Res. J. Adv. Eng. Sci., vol. 4, no. 3, pp. 225-229, (2019), doi: 10.5281/zenodo.3365590.

[11] "Analisis hidrologi / Sri Harto Br. OPAC Perpustakaan Nasional RI." https://opac.perpusnas.go.id/DetailOpac.aspx?i $d=266504$ (accessed Sep. 06, 2021).

[12] A. A. Adihaningrum, V. Dermawan, and D. Chandrasasi, "Rasionalisasi Jaringan Stasiun Hujan Menggunakan Metode Kagan - Rodda 
Dengan Memperhitungkan Faktor Topografi Pada Daerah Aliran Sungai (Das) Sampean, Kabupaten Bondowoso, Jawa Timur," (2017).

[13] Z. R. Alfirman, L. M. Limantara, and S. Wahyuni, "Rasionalisasi Kerapatan Pos Hujan Menggunakan Metode Kagan-Rodda di Sub DAS Lesti," J. Tek. Sipil, vol. 8, no. 2, pp. 153164, (2019). 